\title{
ANALYSIS OF CATALITIC REACTORS USEFULNESS TO REDUCE POLLUTION GENERATED BY PISTON COMBUSTION ENGINES WITH REGARD TO SHIP MAIN ENGINES
}

\author{
Edyta Zielińska, PhD. ${ }^{1)}$ \\ Jerzy Girtler, Prof. ${ }^{2)}$ \\ Kazimierz Lejda, Prof. ${ }^{1)}$ \\ 1) Rzeszów University of Technology, Poland \\ 2) Gdańsk University of Technology, Poland
}

\begin{abstract}
The article presents results which indicate that the use of catalytic reactors to reduce emissions of harmful compunds contained in the exhaust gas is important in the operation of vehicle motors operation. Efforts of the shipbuilding industry to reduce the toxicity of exhaust gas emitted by the main engines have been indicated and pointed to the desirability of the use of these catalysts in maritime transport. It has been pointed out that studies of the harmful substances in exhaust gases performer at vehicle inspection stations have an impact on increasing the safety of drivers and other road users and contribute to preserving the natural environment by reducing the danger coming from cars operating on Polish roads. An opinion has been expressed that the most serious threats to the environment are emitted by car transport exhaust fumes, which are characterized by significant emission of toxic compounds excreted into the atmosphere from tailpipe emissions.

It has been demonstrated that a fully functioning catalytic reactor, operating in a steady state at appropriate temperatures and the composition of the mixture close to stoichiometric ratio, can reduce emissions of carbon monoxide, hydrocarbons and nitrogen oxides by more than $90 \%$. Also, an assessment has been presented reporting the efficiency of catalytic reactors of spark ignition engines operating in a test vehicle inspection station. The results of research in the evaluation of their performance were correlated with their operation waveforms. Such an approach is justified by the fact that during the operation of each vehicle the wear of its assemblies and components is different - including the catalytic reactor. The catalytic layer undergoes aging so that there are changes in the structure and chemical composition of the catalyst bed, while the overlapping of layers of different chemical compounds that block access to the active layer of the reactor.

An opinion has also been expressed that it would be advisable to take steps to use research results presented in this article for research of catalytic reactors similar use in diagnostic systems of marine combustion engines, especially the main ones, which exhaust emissions are incomparably greater than in the case of car engines.
\end{abstract}

Keywords: ship engine, catalytic reactor, the catalytic reactor efficiency, harmful compounds

\section{INTRODUCTION}

In maritime transport, the most important factor is the activity aimed to reduce the pollution in the exhaust gases of combustion engines used for the propulsion of ships (i.e.. main engines). Therefore, the modern ship main engines, especially large of great power, are designed and built taking into account the requirements for environmental protection (maritime especially). The requirements imposed by the regulations of the International Maritime Organization (IMO), which is under pressure from countries pursuing environmental policies developed the Annex VI of the Marpol
73/78 Convent, ordering the protection of the atmosphere of the marine environment from pollution by ships [5, 10, 11]. In this respect, there is significant progress [5]. However, during the operation of the engines, their ecological properties deteriorate, forcing the use of appropriate systems diagnosing adoptees to identify the harmful ingredients contained in the exhaust gas. Particularly important is the determination of such harmful substances contained in the exhaust gases, such as nitrogen oxides $\left(\mathrm{NO}_{\mathrm{x}}\right)$, sulphur oxides $\left(\mathrm{SO}_{\mathrm{x}}\right)$, carbon monoxide (CO), total emissions of hydrocarbons (THC), volatile organic compounds (VOC) and particulate matter 
(PM). Less important is the noise generated by the main engines, especially high powered, because they are low-speed engines. Noise is a major detrimental factor in the case of using engine speed, both as auxiliary power generators and in particular to a high-speed drive of small vessels (e.g. Hydrofoils). It can be expected that a significant acceleration of the process of improving diagnosing these systems to identify the composition of the exhaust gases of these engines might be in the case of adopting the achievements in this regards on car engines.

The car engine research, important from the environmental point of view, currently allow to control emissions and the composition of exhaust gases in the engine with spark ignition, exhaust gases in a diesel engine, correct functioning of the OBD system and the level of external noise [15]. For the most serious threat to the environment they are emitted by motor vehicle exhaust fumes. In order to reduce these pollutants catalytic exhaust gas reactors are used, which during operation of internal combustion engines of these vehicles wear out like other assemblies as well as components and elements of the car, so evaluation of their performance by diagnosticians is very important.

\section{GENERAL COMMENTS ON THE CONDITIONS AND ASPIRATIONS OF MARINE MAIN ENGINES PRODUCERS TO REDUCE EXHAUST EMISSIONS}

Marine vessel propulsion engines produced today are being increasingly equipped, instead of a cam control timing and fuel injection valve, depending on the angle of rotation of the crankshaft, the electronically controlled hydraulic system. This improves the combustion process in the work areas of such engines, which influences their environmental friendly properties as it lowers the amount of emissions of harmful components contained in the exhaust gas. Such engines are also equipped with a device monitoring emissions and other equipment necessary to identify the technical condition of these engines. A diagram showing the surveillance capabilities of the engine, with regard to its technical condition, is shown in Fig. 1.

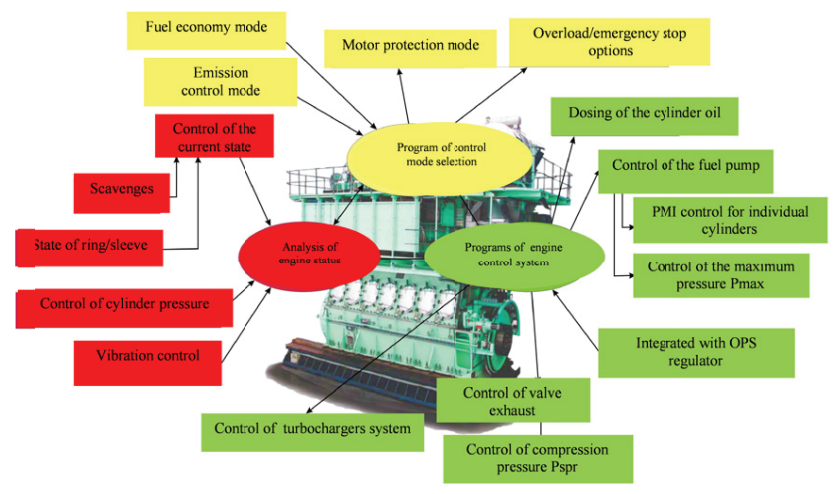

Fig. 1 General scheme of the ship's main engine including the possibility of monitoring of its operation and the mode of emission control $[5,12]$
Manufacturers of such engines strive to provide [5]:

- opacity exhaust gases which are as such when the combustion in the engine operating areas is close to stoichiometric,

- minimalization of the specific fuel consumption $[\mathrm{g} / \mathrm{kWh}]$ and thereby reduction of emissions of harmful substances in the exhaust gases (which are contained in the fuel),

- minimalization of the unit consumption of oil $[\mathrm{g} / \mathrm{kWh}]$ and thereby the reduction of emissions of harmful substances in the exhaust gases (which are included in the lubricating oil).

Conducted studies have led to the determination of impurities, for example such as nitrogen oxides $\left(\mathrm{NO}_{\mathrm{x}}\right)$, sulfur oxides $\left(\mathrm{SO}_{\mathrm{x}}\right)$, carbon monoxide $(\mathrm{CO})$, hydrocarbons $(\mathrm{CH})$, particulate matter $(\mathrm{PM})$ and other like derived from the combustion of lubricating oil. The results of these tests allowed to divide the exhaust gases of marine engines to groups, both in terms of quantity as well as the possibility of controlling the process of their formation [5]. Chemical elements and compounds shown in Table $1[5,9]$ have been accounted to the group of "common - main" exhaust gas components. By contrast, chemical elements and compounds shown in Table $2[5,9]$ have been accounted to the group of "extra" exhaust gas components.

Tab. 1. Concentration of main components of exhaust gases of marine engines with regard to the composition of dry air under natural conditions $[5,9]$

\begin{tabular}{|c|c|c|c|}
\hline Component & Symbol & $\begin{array}{c}\text { The scope of } \\
\text { concentration in } \\
\text { the exhaust gases }\end{array}$ & $\begin{array}{c}\text { Concentration } \\
\text { in dry air } \\
\text { under natural } \\
\text { conditions }\end{array}$ \\
\hline Nitrogen & $\mathrm{N} 2$ & $75 \div 77 \%$ - vol. & $78,08 \%-$ vol. \\
\hline Oxygen & $\mathrm{O} 2$ & $11,5 \div 15,5 \%$ - vol. & $20,95-$ vol. \\
\hline $\begin{array}{c}\text { Carbon } \\
\text { dioxide }\end{array}$ & $\mathrm{CO} 2$ & $4,0 \div 6,5 \%$ - vol. & $\begin{array}{c}\text { about . } 350 \mathrm{ppm} \\
- \text { vol. }\end{array}$ \\
\hline Water & $\mathrm{H} 2 \mathrm{O}$ & $4,0 \div 6,0 \%$ - vol. & $0,934 \%-$ vol. \\
\hline Argon & $\mathrm{Ar}$ & $0,8 \%-$ vol. & - \\
\hline SUMARILLY & - & $>99,7 \%-$ vol. & \\
\hline
\end{tabular}

Limit values of harmful compounds are as follows [5]:

- nitrogen oxides $\left(\mathrm{NO}_{\mathrm{x}}\right)$ - IMO - $17 \mathrm{~g} / \mathrm{kWh}$,

- $\quad$ sulphur oxides $\left(\mathrm{SO}_{\mathrm{x}}\right)$ - special areas (IMO) to 1,5\% $\mathrm{S}$, local limitations e.g. Sweden to 0,5\% S, MAN B\&W 600 ppm (3 \% S), Wartsila - 13,6 g/kWh (3 \% S),

- carbon oxides $\left(\mathrm{CO}_{\mathrm{x}}\right)-\mathrm{IMO}-$ no limits, MAN B\&WCO - 60 ppm, Wartsila - CO - 0,4 g/kWh CO2 - 0,5 $\mathrm{kg} / \mathrm{kWh}$,

- hydrocarbons (HC) - IMO - no limits MAN B\&W 180 ppm, Wartsila - 0,4 g/kWh,

- particulate matter (PM) - IMO - no limits, MAN $\mathrm{B} \& \mathrm{~W}$ - $120 \mathrm{mg} / \mathrm{Nm} 3$, Wartsila - 0,6 g/kWh.

The endeavours of manufacturers of marine combustion engines to reduce the value of such harmful substances contained in exhaust gases, such as $\mathrm{CO}, \mathrm{HC}$ and $\mathrm{NOx}$ could be supported by the achievements of manufacturers of automobile engines obtained in cooperation with scientific institutions which investigate operational properties of 
vehicles with regard to the possibility of use of catalytic reactors.

Tab. 2. Concentration of additional exhaust components of marine engines and their level of concentration with respect to the factors that influence the combustion process [13]

\begin{tabular}{|c|c|c|c|}
\hline Component & है & $\begin{array}{l}\text { The scope of } \\
\text { concentration in } \\
\text { the exhaust gases }\end{array}$ & $\begin{array}{l}\text { The level of } \\
\text { concentration } \\
\text { with regard to the } \\
\text { factors affecting } \\
\text { the combustion } \\
\text { process }\end{array}$ \\
\hline $\begin{array}{l}\text { Nitrogen } \\
\text { oxides }\end{array}$ & $\mathrm{NO}_{\mathrm{x}}$ & $\begin{array}{c}1000 \div 1500 \mathrm{ppm} \\
\text { - vol. }\end{array}$ & $\begin{array}{l}\text { Relatively high if } \\
\text { not controlled }\end{array}$ \\
\hline $\begin{array}{l}\text { Sulphur } \\
\text { oxides }\end{array}$ & $\mathrm{SO}_{\mathrm{x}}$ & $\begin{aligned} 30 \div 900 \mathrm{ppm} \\
- \text { vol. }\end{aligned}$ & $\begin{array}{l}\text { Depending on the } \\
\text { sulphur content of } \\
\text { the selected fuel }\end{array}$ \\
\hline $\begin{array}{c}\text { Carbon } \\
\text { oxides }\end{array}$ & $\mathrm{CO}$ & $20 \div 150 \mathrm{ppm}-$ vol & $\begin{array}{l}\text { Relatively low with } \\
\text { good combustion }\end{array}$ \\
\hline $\begin{array}{c}\text { Total } \\
\text { emission of } \\
\text { hydrocarbons }\end{array}$ & THC & $20 \div 100$ ppm - vol. & $\begin{array}{l}\text { Relatively low with } \\
\text { good combustion }\end{array}$ \\
\hline $\begin{array}{c}\text { Volatile } \\
\text { organic } \\
\text { compounds }\end{array}$ & VOC & $20 \div 100$ ppm - vol. & $\begin{array}{l}\text { Relatively low with } \\
\text { good combustion }\end{array}$ \\
\hline Particulates & PM & $\begin{array}{c}20 \div 100 \mathrm{mg} / \mathrm{Nm}^{3} \\
\text { dry, at } 15 \% \mathrm{O}_{2}\end{array}$ & $\begin{array}{l}\text { Relatively low with } \\
\text { good combustion, } \\
\text { depending on the } \\
\text { ash and sulphur } \\
\text { content in the fuel }\end{array}$ \\
\hline Smoke & - & - & $\begin{array}{l}\text { Linked with small } \\
\text { load, start of the } \\
\text { engine and the } \\
\text { rapid increase in } \\
\text { load }\end{array}$ \\
\hline
\end{tabular}

\section{POSSIBILITIES OF TRANSFORMATION OF SOME HARMFUL EXHAUST GASES EMITTED BY ENGINES INTO HARMLESS SUBSTANCES BY MEANS OF CATALYTIC REACTORS}

It is expected that the achievements in reducing harmful emissions in car engines can be successfully included in forming properties of ecological marine engines when using catalytic reactors. Catalytic reactors allow such a significant reduction in emissions resulting from the combustion process in the engine cylinder that it is possible to comply with the rigorous standards for emissions applicable in road transport. Currently, catalytic reactors are used in a wide variety of transport devices powered by internal combustion engines, including commercial vehicles (trucks, buses), means of handling (forklifts), locomotives, etc. . The modern catalytic reactor is part of the exhaust gas system of all modern passenger cars. It acts outside of the motor system, reducing the amount of harmful chemicals in the exhaust gas.

The catalytic monolith, especially its outer surface promotes the creation of new non-toxic compounds. Depending on the needs and opportunities in shipbuilding one may consider which type of catalysts shown in Fig. 2 should be applied primarily.

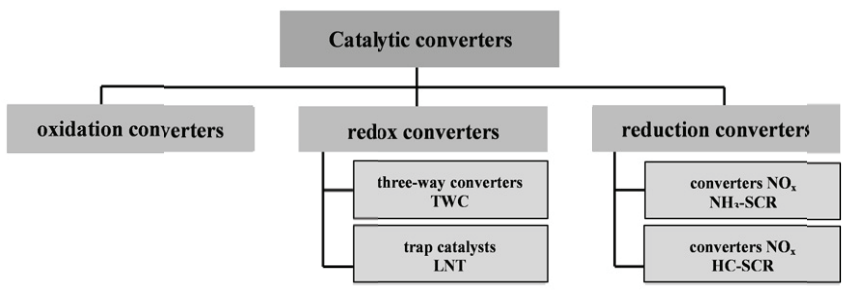

Fig. 2 Classification of catalytic reactors [4]

In the case of motor vehicles with spark ignition the task of the catalytic reactor is to transform harmful exhaust gases, mainly hydrocarbons $\mathrm{HC}$, carbon monoxide $\mathrm{CO}$ and nitrogen oxides $\mathrm{NO}_{\mathrm{X}}$ into harmless substances. Reducing emissions of $\mathrm{HC}$ and $\mathrm{CO}$ is carried out by oxidation and reduction reaction of $\mathrm{NO}_{\mathrm{X}}$ by $\mathrm{HC}$. The purpose of the catalytic reactor is also the acceleration of a chemical reaction or its proper orientation. In the process of purifying exhaust gas the following chemical reactions occur in the catalytic reactor [1]:

- oxidation of $\mathrm{CO}$ and $\mathrm{HC}$ in a singular reactor,

- oxidation of $\mathrm{CO}, \mathrm{HC}$ and reduction of $\mathrm{NO}_{\mathrm{x}}$ in a double reactor,

- $\quad$ oxidation and reduction in a multimode reactor.

A single catalytic reactor is characterized in that the exhaust gas is supplied with additional air to an oxidizing carrier. The source of additional air blower is usually rotary or special valves (SLS). Hydrocarbons contained in the exhaust has are converted to water vapor and carbon monoxide to carbon dioxide. In this type of reactor, the nitrogen oxides are not reduced. Due to increasing demand from emission standards, single catalytic reactors are replaced with systems of several reactors. The double catalytic reactor consists of two carriers arranged in series: a reducing agent, wherein the absence of air is followed by reduction of nitrogen oxides and oxidizing agent, in which the oxidation of hydrocarbons and carbon monoxide occurs. The advantages of the catalytic reactor include a high tolerance fluctuations in the composition of the fuel-air mixture and low cost implementation of the system. Simultaneous oxidation of hydrocarbons, carbon monoxide and nitrogen oxide reduction takes place in a multimode reactor but if the air-fuel ratio in the combustible mixture is near the stoichiometric air excess ratio $(\lambda=1)$. Important here is the continuous adjustment of the composition of the fuel-air mixture in the feedback circuit. The catalytic reactor includes a carrier made as a monolithic ceramic or metal honeycomb, coated with the intermediate layer, the active layer and the sealant layer and insulating heat in the form of mats and closing the entire heat-resistant housing made of corrosion-resistant steel (Fig. 3).

Table 3 shows a comparison of some of the parameters of catalytic reactors with ceramic monoliths and metallic materials. 


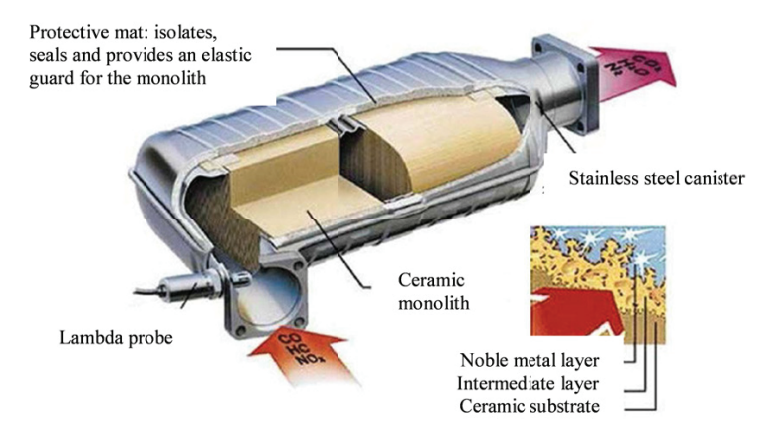

Fig. 3. Elements of the catalytic reactor [8]

Tab. 3. Comparison of selected monolith parameters [8]

\begin{tabular}{|c|c|c|}
\hline \multirow{2}{*}{ Parameter } & \multicolumn{2}{|c|}{ Monolith } \\
\hline & ceramic & metallic \\
\hline $\begin{array}{l}\text { Number of channels [1/ } \\
\left.\mathrm{cal}^{2}\right]\end{array}$ & 400 & 500 \\
\hline Length [m] & \multicolumn{2}{|c|}{0,1} \\
\hline Unit area $\left[\mathrm{m}^{2} / \mathrm{m}^{3}\right]$ & 2100 & 3700 \\
\hline Precious metals $\left[\mathrm{g} / \mathrm{dm}^{3}\right]$ & \multicolumn{2}{|c|}{1,76} \\
\hline Hydraulic diameter [mm] & 1,12 & 0,88 \\
\hline Filling level & 0,69 & 0,73 \\
\hline Thermal conductivity $[\mathrm{J} / \mathrm{m} \cdot \mathrm{s}]$ & 1,657 & 14 \\
\hline Specific heat [J/kg.K] & 1089 & 500 \\
\hline $\begin{array}{l}\text { Monolith material density } \\
{\left[\mathrm{kg} / \mathrm{m}^{3}\right]}\end{array}$ & 2500 & 7300 \\
\hline
\end{tabular}

Operation of the catalytic reactor is the reaction of substances in the exhaust gases with the catalyst. With the engine control based on data from the lambda probe optimum performance of the catalytic reactor is selected. In combustion engines:

- with spark-ignition usually trifunctional TWC (Three Way Catalyst) reactors are used reducing nitrogen oxides and simultaneously oxidizing hydrocarbons and carbon monoxide; for those reactions to occur at the same time it is necessary to maintain the excess air ratio of approx. $\lambda=1$,

- with self-ignition oxidation reactors are used which causes the oxidation of $\mathrm{HC}$ and $\mathrm{CO}$; simultaneous reduction of $\mathrm{NO}_{\mathrm{x}}$ in this case is impossible because of the work of these engines on poor mixtures.

The use of catalytic reactors enables the development of a model of the combustion process in the workspace of the marine engine piston in which one distinguishes the following stages: $s_{1}$ - full combustion (total and utter) $s_{2}$ - incomplete combustion, $s_{3}$ - non-total combustion (incomplete and nontotal), $s_{4}$ - quasi-detonation combustion [2]. The development of this model could rely on the inclusion in the $s_{2}$ stage of this process not only the content of $\mathrm{CO}$ in the exhaust gas, but also $\mathrm{HC}$ and $\mathrm{NO}_{x}$, or on the formulation of a new stage of the process corresponding to only the content of $\mathrm{HC}$ and $\mathrm{NO}_{x}$ in the exhaust gas. In addition, the use of catalytic reactor could contribute to a better use of semi-markowski model of marine diesel engine start-up process developed in order to determine the expected value of the mass of pollutants in the exhaust gases [3]. It is clear that in both cases it is necessary to determine the effectiveness of the catalytic reactors.

\section{METHODS FOR ASSESSING THE EFFECTIVENESS OF CATALYTIC REACTOR TO REDUCE TOXIC EMISSIONS OF ENGINES WITH SPARK IGNITION}

The work of an engine with spark ignition causes the emission of toxic substances contained in exhaust gases into the environment. One way of reducing exhaust emissions is to treat with a properly selected chemical reactions of oxidation and reduction, which are carried out using the catalytic reactor. It includes (in its construction) chemicals that stimulate the components contained in the exhaust gas to overlap in responses between them. During operation of the vehicle it comes to deactivation processes of the reactor which have an impact on the change of the structure and chemical composition of the catalyst bed. It may also come to overlaps of various compounds on the catalytic layer of the reactor. Checking the efficiency of the catalytic reactor can be performed using several methods $[1,6,7]$. One of the methods of monitoring the performance of the reactor in OBDII system is the evaluation of the instantaneous oxygen concentrations before and after the reactor. It is based on analysis of the decline in aerobic capacity of the reactor by evaluating the signals from the oxygen sensor (Fig. 4).

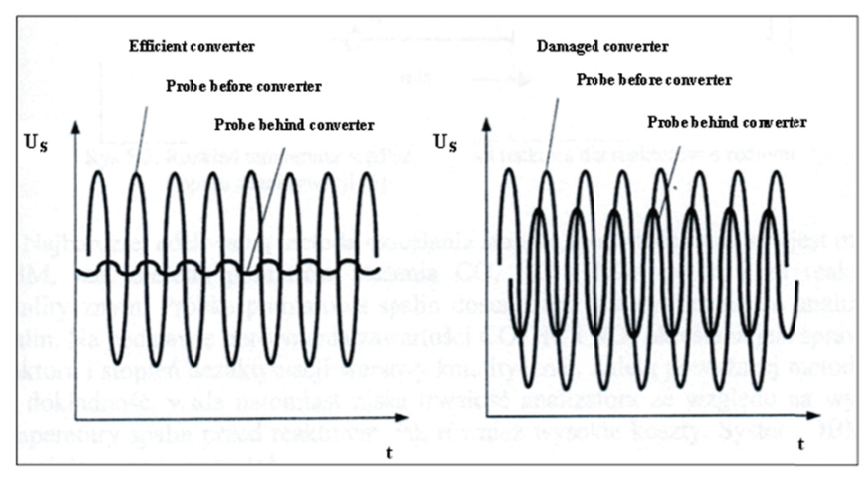

Fig. 4. The voltage signal of the lambda sensors placed upstream and downstream of the reactor [1]

The oxygen content is measured by a lambda sensor, which acts as a galvanic cell. Placement of the sensor in the exhaust system is shown in Fig. 5. 


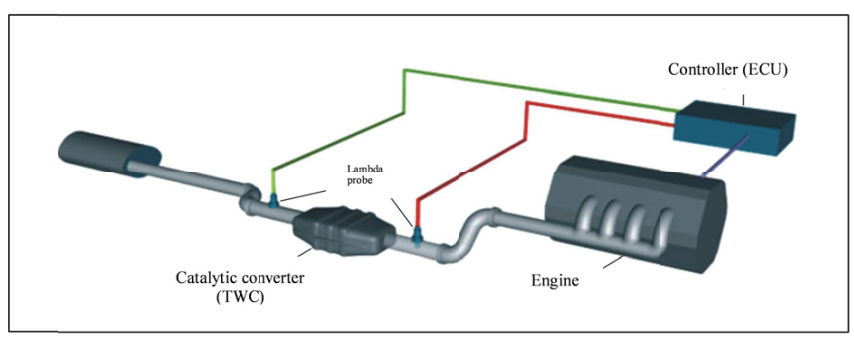

Fig. 5. Car exhaust gas system [15]

One part of the lambda probe is placed in the exhaust stream while the second is in contact with the surrounding air. The oxygen concentration in the exhaust gas is measured at a frequency of approx.. 100 times per second and the correlation of the composition of the fuel-air mixture approx. 300 times per minute. The reaction rate of the sensor is 50 to $100 \mathrm{~ms}$.

Another possibility to verify the effective operation of the reactor is a method of using temperature sensors placed in front of and behind it. The efficiency of the reactors is assessed taking into account the increase in temperature resulting from the exothermic chemical reactions inside. Temperature rises are calculated from the thermal effect of the reactions taking place in the reactor and is the sum of individual gains resulting from the reaction of oxidation and reduction (Fig. 6).

An important method enabling the verification of the efficiency of the catalytic reactor is called the OBM method which is characterized by high accuracy. This is a method for measuring the concentrations of $\mathrm{CO}, \mathrm{HC}, \mathrm{NO}_{\mathrm{x}}$ upstream and downstream of the reactor. In order to measure the exhaust gas, a sample is periodically transferred to the exhaust analyser, which is determined by the efficiency of the reactor and the degree of inactivation of the catalytic layer on the basis of the content of $\mathrm{CO}, \mathrm{HC}$ and $\mathrm{NO}_{\mathrm{x}}$. A disadvantage of this method is the high cost and low reliability of the analyser caused by high temperature of the exhaust gas upstream of the reactor.

Fig. 6. Temperature distribution in reactors with varying degrees of efficiency [1]

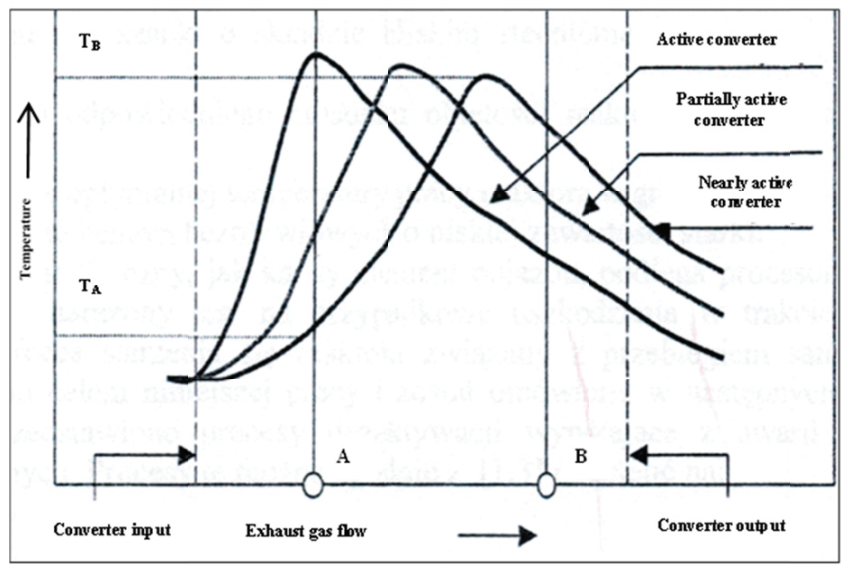

\section{RESEARCH ON THE EFFICIENCY OF CATALYTIC REACTORS}

The aim of the research presented in this paper was to obtain a correlation between the efficiency of the catalytic reactor and vehicle mileage. The study used engines with a capacity of $1391 \mathrm{~cm}^{3}$ and a factory fitted catalytic reactor in cars from the Volkswagen Group (VW, Skoda, Audi and Seat). In these studies, it was assumed that wear and tear on the catalytic reactor is affected by the time of his active work, or distance travelled by the vehicle.

In contrast, the aging process caused by the passage of unused vehicle time was omitted. The study included 140 vehicles divided into 4 groups with an average mileage of: 60, 90, 120 and 150 thousand kilometres. The vehicles were examined repeatedly at 3 selected diagnostics stations (tests conducted over a period of 3.5 years, both in summer and winter).

During these tests, measurements were made using a gas analyser. The efficiency of exhaust gas treatment in terms of $\mathrm{CO}$ and $\mathrm{HC}$ depending on the course of the vehicles operation was determined. The efficiency of the exhaust gas purification was determined as the percent reduction of $\mathrm{CO}$ and $\mathrm{HC}$ in the exhaust gas before and after the reactor. Changes in efficiency of $\mathrm{CO}$ after-treatment depending on the mileage of the vehicle are shown in Fig. 7, while of HC on Fig. 8.

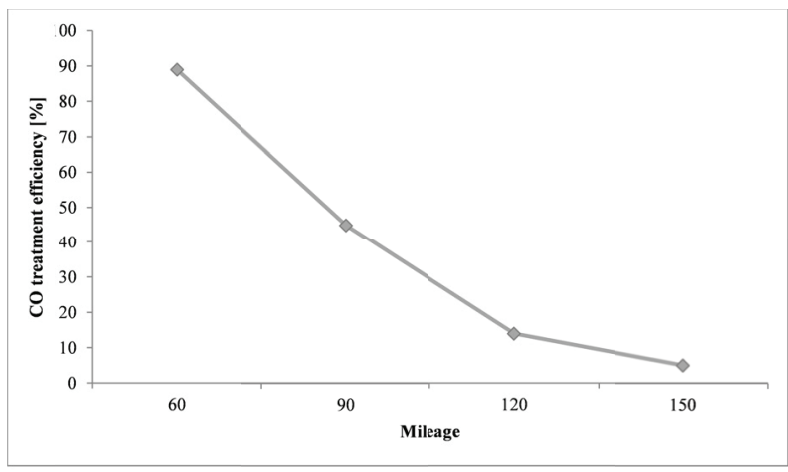

Fig. 7. Empirical course of changes in the efficiency of purification of exhaust gas of $\mathrm{CO}$ in the reactor depending on the mileage of the operated vehicle (own study)

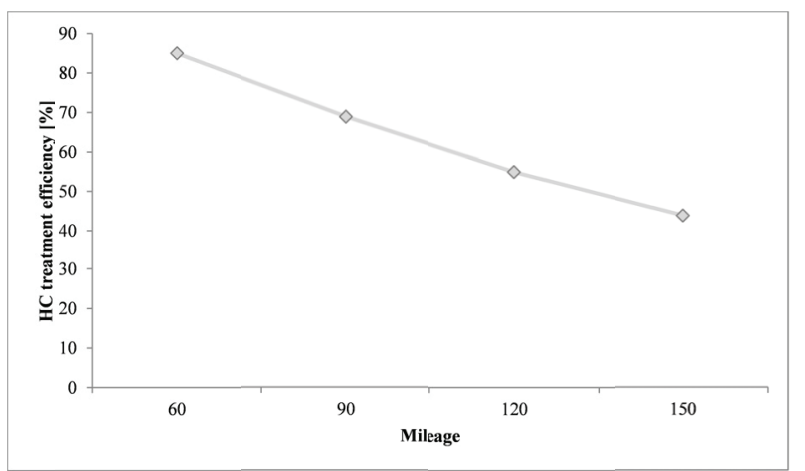

Fig. 8. Empirical course of changes in the efficiency of purification of exhaust gas of $\mathrm{HC}$ in the reactor depending on the mileage of the operated vehicle (own study) 
Analysing Fig. 7 and 8, it can be said that with the vehicle mileage increase the efficiency of the catalytic reactor decreases. It should be noted (Fig. 7), that by the mileage of 60 thousand $\mathrm{km}$ the efficiency of the after-treatment of $\mathrm{CO}$ is approx.. 90\%, and at 150 thousand $\mathrm{km}$ drops only to approx.. $5 \%$. A much better situation comes with the after-treatment of $\mathrm{HC}$, because at 60 thousand $\mathrm{km}$ it was approx. $85 \%$ and at 150 thousand $\mathrm{km}$ it was approx. $45 \%$. Comparison of changes in the efficiency of exhaust has purification of $\mathrm{CO}$ and $\mathrm{HC}$ for the assumed service life of motor vehicles is shown in Table 4 . In contrast, Table 5 presents a summary of changes of mean concentrations of CO and HC.

Tab. 4. Comparison of changes in efficiency of after-treatment of CO and HC (own study)

\begin{tabular}{|c|c|c|c|}
\hline \multirow{2}{*}{$\begin{array}{c}\text { The efficiency } \\
\text { of exhaust gas } \\
\text { purification }\end{array}$} & \multicolumn{2}{|c|}{ Mileage [in thousand km] } & \multirow{2}{*}{ change [\%] } \\
\cline { 2 - 3 } & $\mathbf{6 0}$ & $\mathbf{1 5 0}$ & \\
\hline with CO & 90,5 & 5,4 & 85.1 \\
\hline with HC & 85,7 & 45,6 & 40,1 \\
\hline
\end{tabular}

Tab. 5. Comparison of observed changes of mean concentrations of $\mathrm{CO}$ and $\mathrm{HC}$ during the analysed period of operation (own study)

\begin{tabular}{|l|c|c|c|}
\hline \multirow{2}{*}{ Parameter description } & \multicolumn{2}{|c|}{$\begin{array}{c}\text { Mileage [in thousand } \\
\text { km] }\end{array}$} & $\begin{array}{c}\text { change } \\
\text { [\%] }\end{array}$ \\
\cline { 2 - 4 } & $\mathbf{6 0}$ & $\mathbf{1 5 0}$ & \\
\hline $\begin{array}{l}\text { The concentration of } \\
\text { CO in the exhaust gas } \\
\text { upstream of the reactor } \\
\text { [\%] }\end{array}$ & 0,4812 & 0,5513 & 7 \\
\hline $\begin{array}{l}\text { The CO concentration } \\
\text { in the exhaust gas of the } \\
\text { reactor [\%] }\end{array}$ & 0,0562 & 0,5382 & \\
\hline $\begin{array}{l}\text { The reduction factor of } \\
\text { CO in the exhaust (the } \\
\text { ratio of the concentrations } \\
\text { of CO before and after the } \\
\text { reactor) }\end{array}$ & 9,41 & 1,04 & \\
\hline $\begin{array}{l}\text { The HC concentration in } \\
\text { the exhaust gas upstream } \\
\text { of the reactor [\%] }\end{array}$ & 203,17 & 303,16 & \\
\hline $\begin{array}{l}\text { The HC concentration in } \\
\text { exhaust gases downstream } \\
\text { of the reactor [\%] }\end{array}$ & 28,43 & 167,52 & \multirow{2}{*}{139,09} \\
\hline $\begin{array}{l}\text { The coefficient of } \\
\text { reduction of HC in } \\
\text { exhaust gas (HC ratio of } \\
\text { the concentrations before } \\
\text { and after the reactor) }\end{array}$ & 7,21 & 1,65 & \\
\hline
\end{tabular}

\section{SUMMARY}

The results of this study indicate that the use of catalytic reactors in automobiles contributes to a significant reduction of emissions of hazardous substances by internal combustion engines. It seems reasonable to strive for a similar use of the catalytic reactor to reduce the toxicity of exhaust gases of marine engines, especially the mains which exhaust emissions are incomparably greater than in the case of car engines.

The studies have shown that important diagnostic tests are carried out in vehicle inspection stations, which seek to eliminate the operation of vehicles with inoperative aftertreatment. It is clear that as a result of substantial autonomy of tasks performer of transportation by ship the mentioned possibility of purification of exhaust gases must be integrated into the systems of diagnosing main engines, e.g. MAN B\&W Cocos (Computer Controlled Surveillance System) [13], or diagnostic system by Wartsila CBM (Condition-Based Maintenance) [14].

Among the methods for verifying the efficiency of the catalytic reactors in the vehicle control stations OBM is a noteworthy method that allows high accuracy measurements of CO, HC, NOx before and after the reactor. This method has be used in studies to assess the efficiency of catalytic reactors in spark ignited engines in vehicles from the Volkswagen Group (VW, Skoda, Audi and Seat), the results of which were presented in this article.

The analysis of the efficiency of after-treatment of $\mathrm{CO}$ and $\mathrm{HC}$ clearly shows that with the movement time of the vehicle (the road distance travelled by the vehicle) the efficiency of the catalytic exhaust reactor is reduced, and after travelling for approx. 90 thousand $\mathrm{km}(60-150$ thousand $\mathrm{km})$ the loss of efficiency is almost radical. The distance travelled by the vehicle has a great impact on the decline in the efficiency of the reactor gas cleaning of CO than of HC, which i san important cognitive application.

\section{BIBLIOGRAPHY}

1. Drabik W.: Wpływ okresu eksploatacji reaktorów katalitycznych na sprawność oczyszczania spalin silników samochodów osobowych o zapłonie iskrowym. Praca doktorska, PRz (promotor: prof. Lejda Kazimierz), Rzeszów 2009.

2. Girtler J.: Reciprocating engine work space taking into account load and wear of crankshaft-piston assembly and the theory of semi-Markov processes. Polish Maritime Research, No 3/2016, pp.50-57.

3. Girtler J.: A probabilistic concept of assessment of amount of noxious substances contained in exhaust gas emitted from self-ignition engines. Polish Maritime Research, Special issue 2006/S2, pp.50-57. 
4. Kruczyński S., Danilczyk W.: Ograniczenie możliwości gazów wylotowych silników spalinowych poprzez zastosowanie reaktorów katalitycznych. MOTROL, No9/2007, Lublin, pp. 93-102.

5. Łosiewicz Z.: Probabilistyczny model diagnostyczny okrętowego silnika napędu głównego statku. Praca doktorska. PG, (promotor: prof. Jerzy Girtler), Gdańsk 2007.

6. Myszkowski S.: Trójfunkcyjne konwertery katalityczne. Kompendium praktycznej wiedzy. Dodatek techniczny do WIADOMOŚCI Inter Cars SA nr 47/Grudzień 2012.

7. Tutak W.: Systemy OBD. Nie tylko mechanik. Materiały szkoleniowe z zakresu diagnostyki samochodowej. Projekt w ramach Europejskiego Funduszu Społecznego, Częstochowa 2009.

8. Worsztynowicz-Błażejowska B.: Analiza zjawisk wywołanych przepływem nieustalonego strumienia przez reaktor katalityczny silnika spalinowego. Praca doktorska, AGH (promotor: Prof. Kiełbasa Jan), Kraków 2008.

9. Wright A. A.: Exhaust Emission from Combustion Machinery. MEP Series, Volume 3, Part 20, Institute of Marine Engineers 2000.

10. ME Engine. The only Engine with Fully Integrated Electronic Control. Kopenhaga, MAN B\&W Diesel AS, 2003.

11. Załącznik VI do Konwencji MARPOL 73/78. Przepisy o zapobieganiu zanieczyszczaniu powietrza przez statki oraz Kodeks techniczny NOx. PRS, Gdańsk 2000.

12. The Intelligent Engine. Development Status and Prospects. MAN B\&W Diesel AS., Kopenhaga 2001.

13. CoCoS Ekspert System for Two and Four-stroke Engines Paper No 16, MAN B\&W Diesel A/S, Kopenhaga 1998.

14. Service News from Wartsila Corporation 2 2002/1/2003, CBM for two stroke engines. Kaidara Software, Wartsila Corporation, Helsinki 2003.

15. http://autokult.pl

\section{CONTACT WITH THE AUTHOR}

\author{
Edyta Zielińska \\ e-mail:ezielins@prz.edu.pl \\ Rzeszów University of Technology \\ 12 Powstańców Warszawy St. \\ 35 - 959 Rzeszów \\ Poland
}

